\title{
Identification of Clay Mineral Content Using Spectral Gamma Ray on Y1 Well in Karawang Area, West Java, Indonesia.
}

\author{
Rahmat C. Wibowo ${ }^{1 *}$, Alia Puja Pertiwi ${ }^{2}$, Suci Kurniati ${ }^{3}$ \\ 1*2,3.Department of Geophisycs Engineering, Engineering Faculty, Universitas Lampung, Lampung, Indonesia.
}

\author{
* Corresponding author : rahmat.caturwibowo@eng.unila.ac.id \\ Tel; 081327507517 fax: 0281-638793 \\ Received: January 21, 2020; Accepted: Jul 7, 2020 \\ DOI : 10.25299/jgeet.2020.5.3.4504
}

\begin{abstract}
Northwest Java Basin (NWJB) is one of the proven hydrocarbon basins in Indonesia. The scope of this paper will focus onthe shales and sandstone interval within Y1 well in Karawang area, NWJB, Indonesia.A cored interval from Y1 well was chosen for an investigation of the clay minerology for the gamma-ray activity and with the purpose of determining how the Spectral Natural Gamma (SNG) log could be used as an indicator of source rock and reservoir quality. The Th/U as a redox indicator is used to assert that the shales are of anoxic conditions of shallow marine environments. Despite the relatively high insoluble Th values (60-74.15) ppm, the presence of U in substantial amounts, which only occurs in reducing conditions where it is preserved as a lower insoluble valence $\left(\mathrm{U}^{4+}\right)$ explains for the low $\mathrm{Th} / \mathrm{U}$ values ranging between (5.8-7.1) ppm/ppm. The overall $\mathrm{Th} / \mathrm{U}$ value of the evaluated shales remain less than 25 , where $\mathrm{Th} / \mathrm{U}<25$ is suggestive of marine sediments, whereas $\mathrm{Th} / \mathrm{U}<4$ is indicative of marine black shales of reducing conditions. Although no linear relationship was found between clay content and $\mathrm{K}, \mathrm{Th}$, or $\mathrm{U}$, the K content characteristic three discrete reservoir characteristic (RC). The RC-I has predicted a matrix-supported texture with the highest $\mathrm{K}$ signal, illite and illitised kaolinite are roughly equal in importance as source of K. The RC-II has predicted a grain-supported texture with intermediate $\mathrm{K}$ content. K-feldspar, mica and illite as the main sources. The RC-III has predicted have a low $\mathrm{K}$ content with grain-supported texture and most of the $\mathrm{K}$ is hosted in feldspar. Overall, the laboratory measurements appear to be applicable to the log data, and, using SEM or XRD, the detail facies subdivision can be extended throughout the source rock and reservoir section based on the SNG log.
\end{abstract}

Keywords: Clay Minerals, SNG, Northwest Java Basin, Source Rock, Reservoir

\section{Introduction}

Natural gamma-ray wireline logging is commonly usedfor lithological, or more precisely mineral, identificationin boreholes. In sandstone reservoir sections, its mainpurpose is to obtain an indication of the clay contentand thus, reservoir quality. Schlumberger (1982) hasdescribed two types of gamma-ray logs: the conventionalGamma Ray log records the total natural gamma radiation in the borehole independent of the energy of thegamma rays, whereas the Spectral Natural Gammaray(SNG) probe measures the gamma-ray spectrum, i.e. theenergy distribution of the gamma rays. The gamma raysoriginate from the decay of radiogenic potassium $\left({ }^{40} \mathrm{~K}\right)$,thorium $\left({ }^{232} \mathrm{Th}\right)$ and uranium $(238 \mathrm{U})$, each of whichexhibit a characteristic energy spectrum. The measuredenergy spectrum is transformed into concentrations ofK, Th and U (Schlumberger 1982).

The advent of various instrumentation such as the Spectral Gamma Rays (SGR) detector has gained acceptance in the global energy industry as an important nondestructive, automated, rapid and inexpensive surveytool for petro-mineralogical and geophysical assessment using radio-isotropy as its mode of determination of clay content, evaluation of clay mineralogy, identification offissure zones, organic matter quantification, reservoir charac-terization, source rock evaluation and depiction of sedimentary conditions and processes which proves their wide acceptance in the areas of sedimentology and stratigraphy
(Ruffell et al., 2006; Schnyder et al., 2006; Klaja \& Dudek, 2016).

In the Y1 well of the Karawang area, SNG core analysis was performed in order todifferentiate micaceous sand from shale. The purpose ofthis study was to identify the radioactive minerals in the shale and sandstones, and to estimate their contribution to thegamma-ray spectrum. Furthermore, the aim was to identify the gamma-spectral characteristics of intervals withdifferent source rock and reservoir quality. With these objectives, wesampled the cores of Y1 and defined three reservoir characteristics (RC) based on SNG log pattern. The three characteristics chosen are expected to havereservoir qualities.

\section{Northwest Java Basin}

NWJB area is part of backarc basin series in Western part of Indonesia. This basin is spreading in west toeast and have a boundary with Sunda Platform in southern area. NWJB have complex configuration fromstructure prespective. Most of this basin is half graben structure that have north to South orientation. Ingeneral, this basin is divide into four sub-basins; those are Ciputat-Kepuh sub basin, Pasir Bungur sub basin,Cipunegara sub basin, and Jatibarang sub basin (Figure 1).

NWJB is extensional basin formed in Tersier; this basin is a part of sunda land (Figure 2). This basin evolved intowrenched-induced pull apart basin during EoceneOligocene, this result in creation of faulted highs andhalf graben system. The structural trend of normal faulting is south to north and is known as thesunda faulttrend. During 
this stage, deposition of lacustrine andvolcanic (Jatibarang Formation) happened.The Jatibarang Formation considered as Eocene-middle Oligocene age, it consist of interbedded Volcanicsmaterial including tuffs, lava, and breccia tuff. This deposition is overlain by deposition of fluvio deltaicTalang Akar Formation during early to late Oligocene.

Talang Akar Formation (TAF) is divide into Lower TAF and upper TAF. Lower TAF consist of silisiclasticrocks deposited in fluvial environment; consist of severalgood reservoir such as conglomeratic reservoirand fluvial sand reservoir. Upper TAF deposited in deltaic to shallow marine environment, consist ofintercalation shand-shale and clastical carbonate at upper part. Batu Raja Formation (BRF) deposited inpost-rift phase during early Miocene, consist of bioclastic carbonate and reefal carbonates. This formationbecame one of the best reservoir in NWJB.
The Cibulakan Formation deposit in shallow marine environment, it consist of mixture of clastic andcarbonate rocks mostly dominated by shale and thin bed ofsandstone. In the middle of this formation, reefalcarbonate deposit, many author called it Mid Main Carbonate (MMC). In the upper part of this formationfacies changing happened, and mostly consist ofcarbonate rock, this is where Parigi Formation is deposite.

Parigi Formation deposited in shallow marine platform, mainly formed as flat reef. In seismic section,this formation is easy to identifie. Parigi Formation consist of fine-grained limestone, shally, lime muds andpackstone-wackstone facies. This Formation is mainly deposite in local high that have relative orientationof North to South. This formation is overlay by the Cisubuh Formation, which is the youngest Formationin NWJB, dominated by carbonaceous shales and thin sandstone (Bishop, 2000).

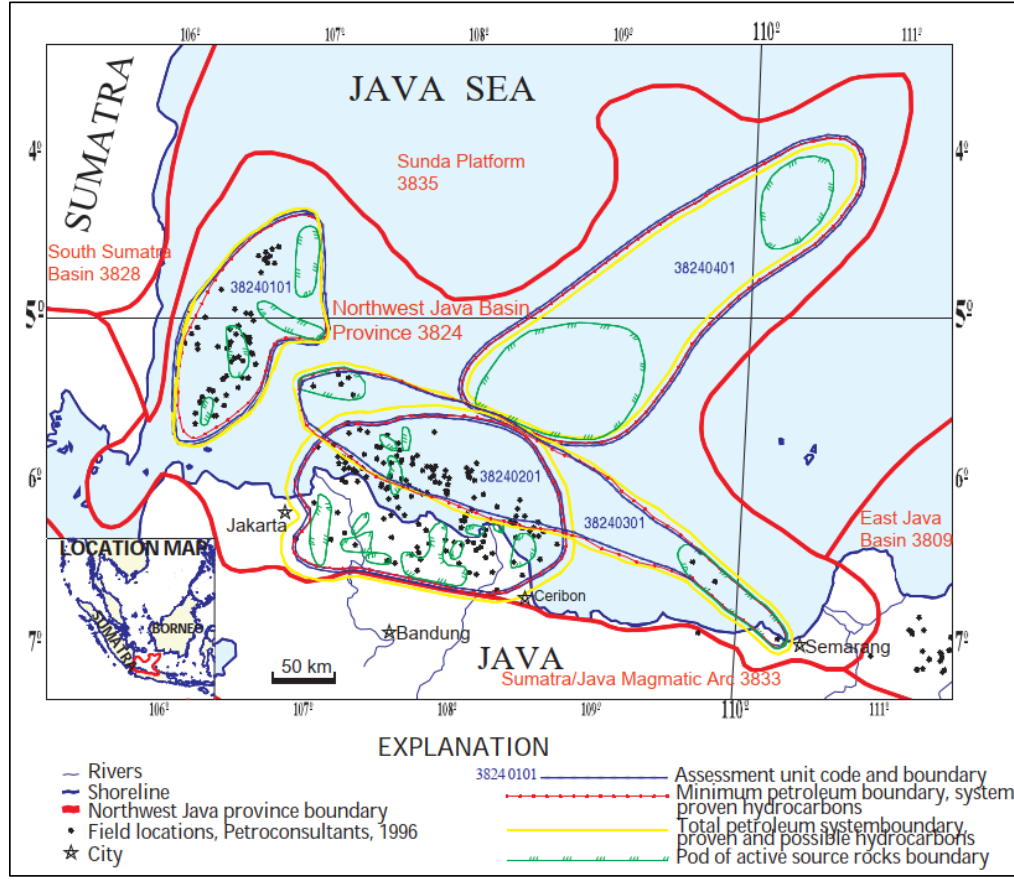

Fig 1. Index map of Northwest Java Basin Province, Indonesia (Bishop, 2000).

\section{Geochemistry of potassium, thorium, and uranium}

Hassan et al. (1976) examined the mineralogy and chemical composition of 500 samples of varying lithology from different environments of deposition. Of particular relevance to this work, their data included $\mathrm{K}$, Th and $\mathrm{U}$ measurements. The following conclusions concerning the occurrence of these three elements are based on Hassan et al. (1976) as well as Schlumberger (1982), and Nielsen et al. (1987).

\subsection{Potassium (K)}

Potassium is a major element in many rock-forming minerals. The radioactive isotope $40 \mathrm{~K}$ constitutes $0.0118 \%$ of the total potassium in a mineral, and the gamma signal from the radioactive decay is an important indicator of mineralogical composition. The most common K-bearing minerals in sedimentary rocks are K-feldspar, mica and illite. K-feldspar and mica are more common in sandstones, illite in shales. K-feldspar and mica have a greater $\mathrm{K}$ content than illite, and thus the gamma-ray flux is only a measure of clay content in the absence of significant K-feldspar (Cowan \& Myers 1988). Glauconite can also be a significant source of $\mathrm{K}$ in sedimentary rocks. Typical potassium contents of K- bearing minerals are: illite, 4.5\%; muscovite, 7.9-9.8\%; plagioclase, 0.54\%; K-feldspar, 10.9-14.0\% (Nielsen et al. 1987). Engstrøm (1981) measured K, Th and U in Danish Cenozoic strata (clay, silt and sand) and found results in accordance with the distributions and concentrations mentioned above. Kaolinite is sometimes reported to contain minor amounts of $\mathrm{K}$ and $\mathrm{Th}$, but ideal kaolinite contains neither elements.

Straightforward relationships between $\mathrm{K}$ and clay content should not be expected. In Miocene-Pliocene shales from the North Sea, Berstad \& Dypvik (1982) found a positive correlation between $\mathrm{K}$ and the clay content. This was inferred to be mainly controlled by the illite of the clay fraction. On the contrary, in Paleocene and Eocene strata, radioactivity and clay content are negatively correlated. This is probably because the clay fraction is rich in a K-poor smectite, derived from basaltic volcanic material.

\subsection{Thorium (Th)}

Thorium is a common trace element in most geological environments. In weathering environments, it is practically insoluble and is thus commonly concentrated in residual deposits such as bauxite and clay. Important quantities of thorium are found in the heavy minerals' monazite, rutile 
and zircon. Zircon normally contains $100-2500 \mathrm{ppm}$ Th (Nielsen et al. 1987), while monazite may contain substantially more.

Pure clay samples typically contain 5-30 ppm Th (Adams \& Weaver 1958). Theoretical considerations indicate that $\mathrm{Th} 4+$, with an ionic radius of $0.97 \mathrm{~nm}$, cannot be accommodated in the layer structure of clay minerals, so that Th in these minerals could be assumed to be fixed by adsorption (Adams \& Weaver 1958). Hurst \& Milodowski (1994) stated, however, that the origin of Th in clay minerals is unclear, and proposed that it is caused by inclusions of clay-sized heavy minerals. In the samples of Hassan et al. (1976), the Th content correlated with the content of clay minerals, but it was not proven that the clays were responsible for the Th enrichment.

\subsection{Uranium (U)}

Under neutral pH conditions, the uranyl ion ((UO)2+) forms ionic complexes with carbonates, which control its dispersion and mobility in nature. The uranyl ion also forms numerous complexes with organic compounds (e.g. humic acids), which facilitate its fixation by organic and mineral matter. Hassan et al. (1976) found that U shows a strong correlation with organic carbon, probably because UO2 precipitates under reducing conditions. Factors other than the content of organic matter (such as the availability of $U$ ) may be important for the occurrence of $U$ in sediments as exemplified by the data of Berstad \& Dypvik (1982). In shales from the Cenozoic of the North Sea, these workers found no correlation between $U$ and Total Organic Carbon (TOC). Uranium also occurs as a trace element in accessory minerals (zircon contains 300-3000 ppm U; Nielsen et al. 1987) and in colloidal Fe-oxide/hydroxide coatings on mineral grains. Uranium species may also be adsorbed onto clay minerals.

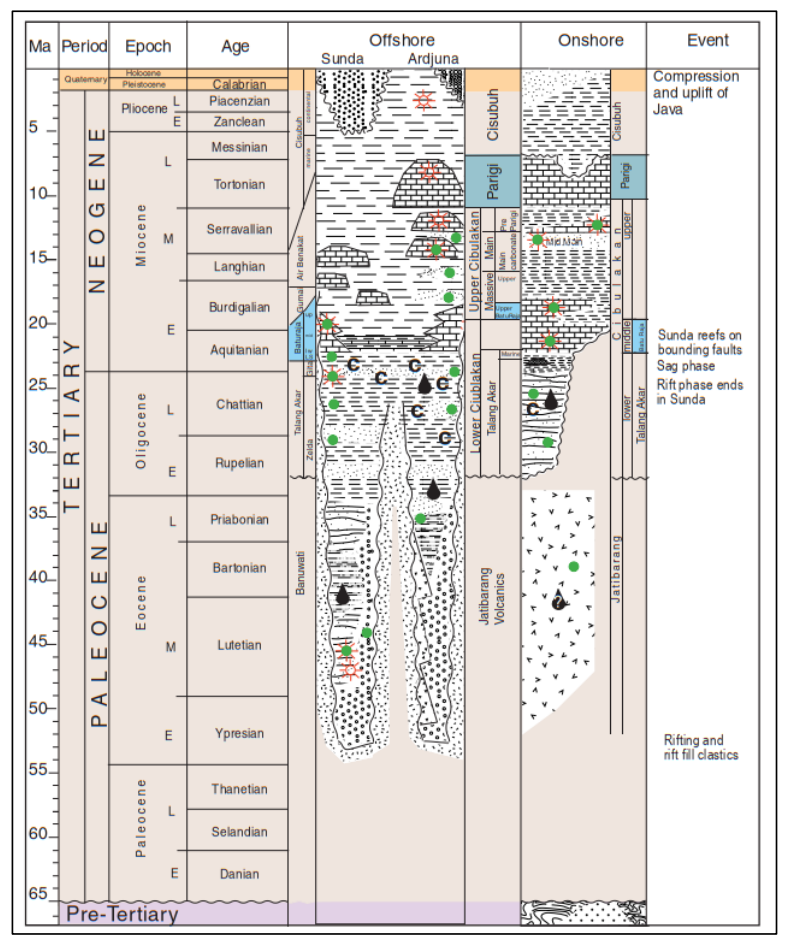

Fig 2. Generalized stratigraphic columns for the Northwest Java Basin Province (Bishop, 2000).

\section{Methods}

\subsection{Borehole Gamma-Ray}

Gamma ray log is a curve where the curve shows the amount of radioactive intensity that is in the formation. This log works by recording the natural gamma ray radiation of rocks, making it useful for detecting or evaluating deposits of radioactive minerals such as Potassium (K), Thorium (Th), or Uranium ore (U). In sedimentary rocks many radioactive elements are concentrated in shales and clays, so the size of the radioactive intensity will indicate the presence or absence of clay minerals. Rocks that have high clay content will have high radioactive concentrations, so that the gamma ray value is also high, with deflection curves to the right.

The main radioactive element is potassium which is commonly found in illites. On a clean permeable layer, a gamma ray log curve will show very low radioactive intensity, except if the layer contains certain minerals that are radioactive, or the layer containing saltwater containing dissolved potassium salts. Radioactive elements are mostly contained in shale layers, so gamma ray logs are very useful for determining the size of flakes or clays. The gamma ray log records radioactive elements on an API (American Petroleum Institute) scale. The basic unit is CPS (Count Per Second) which is then converted to API after being calibrated with a formation that has known exactly the radioactive mineral content $(\mathrm{U}, \mathrm{Th}$, and $\mathrm{K})$. The uses of this gamma ray log include determining shale (Vsh) content, clay content, determining permeable layers, evaluating radioactive ore minerals, evaluating non-radioactive mineral layers, and correlations between wells.

Clay content is one of the important parameters that affect source rock and reservoir properties by using a gamma ray log that records the amount of natural radioactivity of rocks.

\subsection{Laboratory Gamma-Ray}

Determination of clay mineral content is limited to five typical minerals that are significant for the oil industry, namely chlorite, glauconite, illite, kaolinite and smectite. Clay minerals formed in continental and marine environments influence variability with respect to chemical composition. The type of clay mineral produced is strongly influenced by environmental reactions of sediments and diagenesis. The dominant clay mineral type can be determined based on the thorium-to-potassium cross plot in Figure 3. The correct grouping of plotted points makes it possible to eliminate several types of clay minerals.

Likewise, the results of conventional gamma logging, gamma ray spectral results can be influenced by the diameter of the borehole and drilling fluid and in the borehole casing by the pipe column and cement bond. Evaluation of clay mineral types using boreholes so that after processing can be carried out which aims to determine the type of minerals by interpreting the cross plot, the interpretation includes determining the type of clay mineral based on a cross plot of potassium to thorium ratio, can be seen in Figure 3.

Similar techniques can be used for laboratory measurements of gamma radiation from $\mathrm{K}$, Th and $\mathrm{U}$ in rock samples. Laboratory measurements were obtained with $\mathrm{NaI}$ crystals using three energy windows centred around the three most prominent gamma energy $\mathrm{K}$, Th and U peaks of the spectrum (Figure 4). These measurements are in the high-energy part of the spectrum and thus less dependent on geometry, density and matrix influence. However, by using only counts from a fraction of the spectrum, longer counting times are needed. 


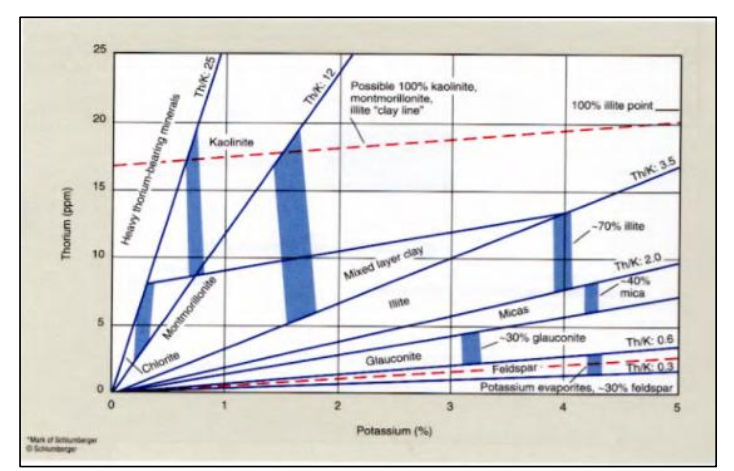

Fig 3. Interpretation of Mineral Clay Based on the Thorium and Potassium Ratio (Schlumberger, 1985).

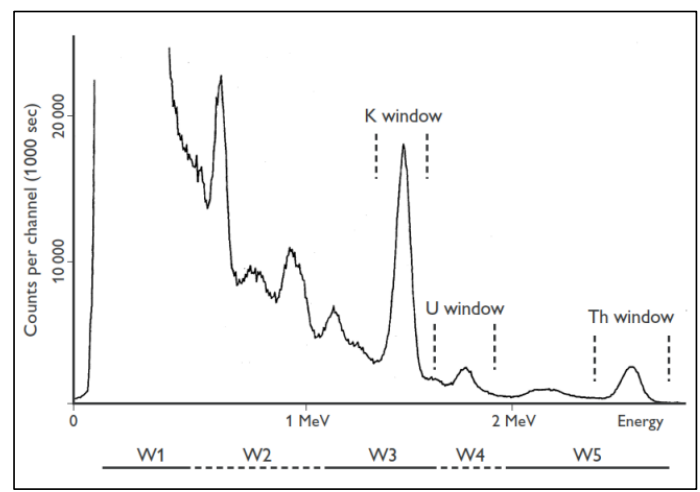

Fig 4. Natural gamma-ray spectrummeasured in the laboratory with a NaIcrystal. Energy windows used forconcentration determinations are centredaround the three most prominent high-energy K, Th and U peaks. (Fabricius et al., 2003)

\subsection{Gamma-Spectral Analysis}

Averaged data of shales and sandstonewas recorded (Figure5). Overall, the total count of gamma radiation follows a consistent pattern for all shales, where the highest radioactivity is Th counts with intermediate $U$ and lower $K$ counts relatively. The response indicates that the decay of isotopes of these shales are of common shales (Fertl, 1979). Comparatively, the shales from the bottom part show close range of Th, $\mathrm{U}$ and $\mathrm{K}$ decay. Upper part shales also show similar radioactive emission, with generally generatinghigher radiation.

Potassium concentrations are low in RC III samples (< $0.7 \%)$, higher in RC II samples (0.6-2\%),and highest in RC I (generally $>2 \%$ although one sample contains $1.2 \% \mathrm{~K}$; Figure 5). This differentiation of RC in terms of $\mathrm{K}$ content was not observed for the clay fraction. Considering all the data, the K content of the clay component shows a weak decrease with increasing depth to around $2177.5 \mathrm{~m}$; at greater depths, the data show considerable scatter but appear to broadly increase between 2177.5 and $2188 \mathrm{~m}$ (Figure 5). The Th and U concentrations of the total samples are variable in RC III and II, but uniformly high in RC I (Figure 5). The Th content in the clay fraction follows roughly the same pattern as the K content, while no pattern is apparent for the $U$ content of the clay fraction (Figure 5). For RC II and I sample, roughly constant Th/K ratios of 9 15 (ppm/\%) were obtained, whereas RC III sample show significant variation in this ratio $(2-47 \mathrm{ppm} / \%)$. This is a consequence of RC I samples being low in $\mathrm{K}$ but having variable Th and $U$ contents; it is assumed that this variability is governed by the heterogeneous distribution of heavy minerals within the facies.

\section{Results and Discussion}

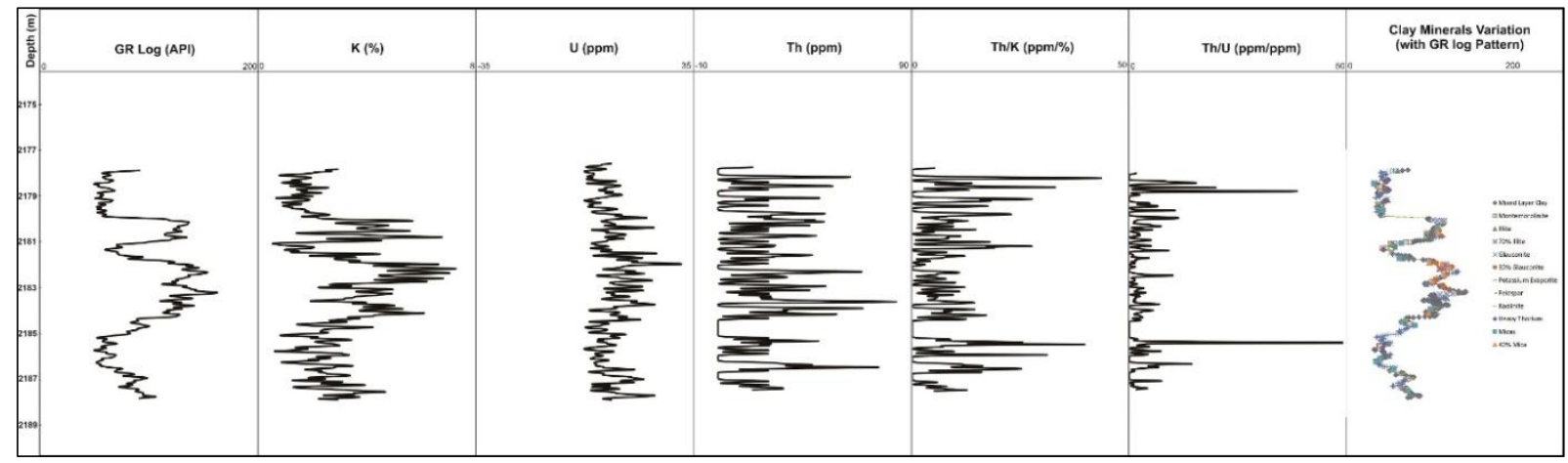

Fig 5. The natural spectral gamma-ray log over the coredinterval of Y1. Intervals in which the $\mathrm{K}$ content is $<0.7 \%$ are referred toRC III, those with $0.7-2 \% \mathrm{~K}$ are referred to RC IIand the sediments with $>2 \% \mathrm{~K}$ are assigned to RC I.The corresponding lithofacies of the core samples, as determined by laboratory measurements.

\subsection{Thorium and Potassium Ratio for Clay Type}

Th/K ratio was computed using Fertl (1979) clay type procedure as diagnostic for determination of the dominant clay minerals. The averaged $\mathrm{Th} / \mathrm{K}$ of all shales are predictive of mixed layer clays $(\mathrm{Th} / \mathrm{K}>3.5$ but $<10)$. The shales show high $\mathrm{K}$ values as compared to lower $\mathrm{K}$. The shales thus tend to have higher $\mathrm{Th} / \mathrm{K}$ values and skew towards the smectite region of mixed layer clays whilst the bottom part shales skew into the illitic region of the mixed layer clays. Predominance of clay minerals shown by the mineralogical plot (Figure 6) by Quirein et al. (1982) validate Fertl (1979) as mixed layer clays.

\subsection{Discussion}

$\mathrm{Th} / \mathrm{U}$ is instrumental in evaluation of depositional environment as it functions as a redox indicator. $U$ is geochemically mobile and more soluble than Th thus prone to mobilization during leaching and clay mineral diagenesis. Therefore, under reducing conditions U6+ takes on the lower valence as $\mathrm{U}^{4+}$ and becomes insoluble producing low Th/U. On the contrary, oxidizing conditions are indicated by high Th/U (Schnyder et al., 2006; Klaja \& Dudek, 2016). Basically, as recorded (Fig 5), Th/U $<25$ for shales from all members is indicative of reducing conditions as discussed by (Klaja \& Dudek, 2016) where Th/U $<25$ is generally affiliated to marine depositional environments. Although further distribution of $\mathrm{Th} / \mathrm{U}$ shows that, $\mathrm{Th} / \mathrm{U}<4$ is of deep 
marine depositional environments, and typical of black shales. Th/U from radioactive decay in this paper shows an estimate of $78 \%$ of (Th/U: $<25$ and $>4$ ) which is proposed by Adams \& Weaver (1958) as of transitional environment, grey and green shales of shallow marine (Klaja \& Dudek, $2016)$ and $22 \%$ of (Th/U < 2) indicative of black shales. An overall assertion infers a marine depositional environment of the shales.

Clay mineralsare helpful in studying the hydrocarbon generation of theshales because a common coincidence exists between their temperatures for oil and gas generation. Convincing evidence and research have proven that, mixed-layer clays are not a continuous solid solution, but mixtures of dioctehedral phases with very little compositional variations (Aagaard \& Helgeson, 1983). The spectral gamma ray technique is unable to differentiate the evolution of mixed-layer I/S clays, although estimate projections are made from the mineralogical plot of $\mathrm{Th} / \mathrm{K}$ (ppm/\%) (Figure 6), bottom part shales may be considered as showing dominance illite in mixed-layer I/S clays whilst upper part shales are considered as dominant in smectite in mixed-layer I/S clays.

Mixed layer clays exist here as a geothermometer and indicator of thermal maturity based on the concept first applied in detailed studies of the Gulf Coast (Hoffman \& Hower, 1979). The transformation of clay minerals during diagenesis is from montmorillonite to mixed-layer smectite/illite to illite (Jiang, 2012). During earlydiagenesis, maturity of the source rock is relatively low and smectite favors the percentage of illite-smectite mixed layer clays. With time and thermogenic conditions, clay minerals lose water and at this point become oil generative until smectite are converted to more illites percentages of the mixed layer in order to favor the expulsion of dry gas (Jiang, 2012).

The progression of this activity produces a series of smaller hydrocarbon molecules of higher volatility and hydrogen content, thus favoring the culmination of methane gas. With evolving kerogen by thermal maturation, the chemical composition of the shale changes progressively with increasing carbonaceous content and reverse of hydrogen content (McCarthy et al., 2011).

The upper part shales $(2180-2181 \mathrm{~m})$ may thus be considered less diagenetically and geothermo-metrically mature (less gas prone) as relative to the bottom part (2182 $-2184 \mathrm{~m}$ ) shales of more progressive evolution (K rich). The illite favored mixed-layer clays are less expandable in contrast to the smectite favored mixed-layer clays. Smectite has a large sorption capacity relative to illite, but the presence of moisture in its expandable structure can greatly reduce gas-sorption capacity. A high maturity gas window usually exists in shales which have most of the smectite content converted to illite (Gasparik et al., 2013). The shales of the bottom part members are considered more gas viable with respect to clay mineral type inference of $\mathrm{Th} / \mathrm{K}$.

The samples ofthe three RC are most effectively separated onthe basis of the $\mathrm{K}$ content. Thus grainsupported porous (clay-poor) (RC I) contain $<0.7 \% \mathrm{~K}$, grain-supported, clay-rich quartz arenites (RC II) contain $0.6-2 \% \mathrm{~K}$ whereas the matrix-supportedwackes of RC III contain $>2 \% \mathrm{~K}$. In Figure 5,the distribution of these three $\mathrm{RC}$ is presented,calculated on the basis of (corrected) log data. RC II occurs throughout the section but particularlydominates the uppermost interval where it is interpreted to represent a lower shoreface sedimentary environment.RC I, showing good reservoir properties, is common in the NWJB where it typically occurs within channel-fill sections of progradation shelf edge facies (Ginanjar et al., 2019). The clay-dominated RC III is mainlyfoundin the lower part of the studied section which is interpreted to represent an shallow marine sedimentary environment (Ginanjar et al., 2019). Schlumberger (1982) reported how the NSG tool candifferentiate between different types of sandstone. Feldspathic sandstones or arkoses will typically have Th/Kratios less than $1 \times 10-4$, because of their low Th and theirhigh $\mathrm{K}$ contents whereas micaceous sandstones have aTh/K ratio close to $2.5 \times 10-4$ because of the presenceof Th-bearing heavy minerals. The $\mathrm{Th} / \mathrm{K}$ ratios in clay-bearing sandstones are still higher. This is consistent withthe present clay-bearing samples (RC II and I)which have $\mathrm{Th} / \mathrm{K}$ ratios of $9-15$ (ppm/\%). By contrast, this ratio varies widely in the RC III samples (Th/K: $2-47 \mathrm{ppm} / \%$ ), depending on the feldsparand heavy mineral content. Thus, high $\mathrm{Th} / \mathrm{K}$ ratios canbe found in mineralogically mature RC III sandstones. The lithofacies as defined in this study are expectedto reflect the reservoir quality of the rock, but they cannot be predicted from the Th/K ratio. Hurst (1990) alsofound Th/K cross-plots to be poorly suited to identifying and quantifying the clay mineralogy of sandstones.

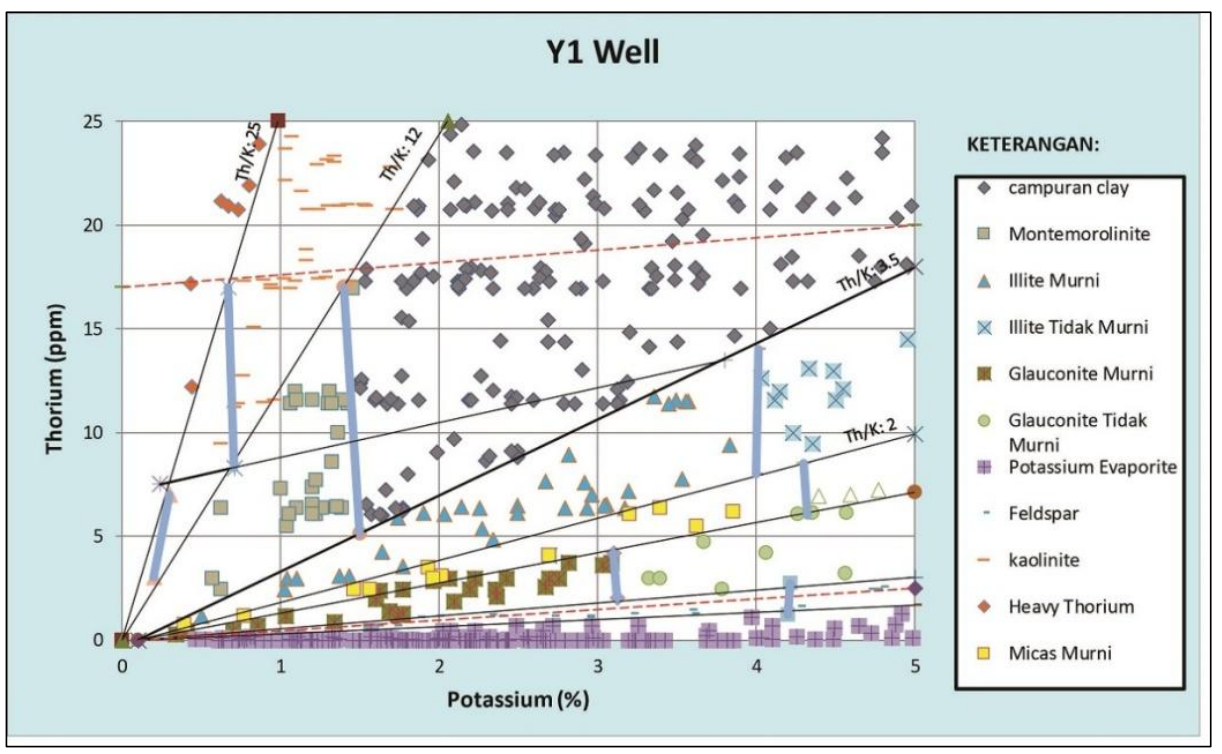

Fig 6. A mineralogical chart of $\mathrm{Th} / \mathrm{K}$ ratio chart for dominant minerals 


\section{Conclusion}

1. Neither gamma-spectral K nor Th was found to bea measure of clay content, but the $\mathrm{K}$ concentrationprovides a method of recognising the three broadlithofacies adopted here. Porous quartz arenites haveK concentrations below $0.7 \%$, grainsupported quartzarenities with pore-filling clay have $\mathrm{K}$ concentrationsbetween 0.6 and $2 \%$, while matrix-supported wackesnormally have $\mathrm{K}$ concentrations above $2 \%$. It is possible, therefore, to define the lithofacies on the basisof the $\mathrm{K}$ signal of the Spectral Natural Gamma log.

2. The shales of the Belaga Formation are of marine depositional environments and typically range fromgrey to black shales and are interpreted as dominant in mixed-layer illite-smectite from $\mathrm{Th} / \mathrm{K}$ evaluation. Perhaps, the more diagenetically mature Layar, Kapit and Bawang shales from clay mineralogy perspective are more conducive to gas generation relative to the shales of the Pelagus and Metah shales. However, this method needs conjunctive mineralogical laboratory analyses to undoubtedly consider diagenesis as well as decipher if clays are detrital or authigenic.

3. Organic matter is preserved under reducing conditionswhere $U$ is concentrated. This relationship makes $\mathrm{U}$ a good indicator of organic matter. From previous studies, $(U>5)$ is usually considered as cut-off for black shale. Generally higher $\mathrm{U}$ values than $\mathrm{K}$ of the all shales in this study may require a follow-up TOC and Rock-Eval pyrolysis to support organic matter richness and maturity for gas generation.

4. The $\mathrm{Th} / \mathrm{K}$ ratio does not give an indication of the lithofacies in this study. Clay-bearing samples (those oflithofacies II and III) have Th/K ratios of $3 \times 10-4$ $-10 \times 10-4$, whereas in the lithofacies I samples thisratio varies widely (Th/K: 2 × 10-4-22 x 10-4) depending on the content of feldspar and heavy minerals.

\section{Acknowledgements}

We would like to thank LEMIGAS for allowing us to conduct research there. Also we have gained a lot of knowledge from this research.

\section{References}

Aagaard, P. \& H. C. Helgeson, 1983. Activity/composition relations among silicates and aqueous solutions: II. Chemical and thermodynamic consequences of ideal mixing of atoms on homological sites in montmorillonites, illites, and mixed-layer clays. Clays and Clay Minerals, 31(3), 207-217.

Adams, J.A.S. \& Weaver, C.E., 1958. Thorium-to-Uranium ratios as indicators of sedimentary processes: example of concept of geochemical facies. American Association of Petroleum Geologists Bulletin 42, 387430.

Berstad, S. \& Dypvik, H., 1982. Sedimentological evolution and natural radioactivity of Tertiary sediments from the central North Sea. Journal of Petroleum Geology 5, 77-88.

Bishop, M.G., 2000. Petroleum Systems of The Northwest
Java Province, Java and Offshore Southeast Sumatra, Indonesia, USGS report, Denver, 34.

Cowan, D.R. \& Myers, K.J., 1988. Surface gamma ray logs: a correlation tool for frontier areas: discussion. American Association of Petroleum Geologists Bulletin 72, 634-636.

Fabricius, I.L., Fazladic, L.D., Steinholm, A., \& Korsbech U., 2003. The use of spectral natural gamma-ray analysis in reservoir evaluation of siliciclastic sediments: a case study from the Middle Jurassic of the Harald Field, Danish Central Basin. Geological Survey of Denmark and Greenland Bulletin 1, 349-366.

Fertl, W. H., 1979. Gamma ray spectral data assists in complex formation evaluation. The Log Analyst, 20(05), 3-37.

Gasparik, M., A. Ghanizadeh, Y. Gensterblum \& B. M. Krooss, 2013. "Multi-temperature" method for high-pressure sorption measurements on moist shales. Review of Scientific Instruments, 84(8), 085116.

Hassan, M., Hossin, A. \& Combaz, A., 1976. Fundamentals of the differential gamma ray log - Interpretation technique. Society of Professional Well Log Analysts 17th Annual Logging Symposium, June 9-12, 1976. Transactions, Paper H, 18 pp.

Hoffman, J. \& J. Hower, 1979. Clay mineral assemblages as low grade metamorphic geothermometers: application to the thrust faulted disturbed belt of Montana, USA. SEPM Special Publication, 26, 55-79.

Hurst, A., 1990. Natural gamma-ray spectroscopy in hydrocarbon-bearing sandstones from the Norwegian continental shelf. In: Hurst, A., Lovell, M.A., \& Morton, A.C. (eds): Geological Applications of Wireline Logs. Geological Society Special Publication (London) 48, 211-222.

Hurst, A. \& Milodowski, A., 1994. Characterisation of clays in sandstones: thorium content and spectral log data. Society of Professional Well Log Analysts 16th European Formation Evaluation Symposium, October 11-13, 1994. Transactions, Paper S, 18 pp.

Jiang, S., 2012. Clay minerals from the perspective of oil and gas exploration. In: Marta Valaskova (Ed.), Clay Minerals in Nature-Their Characterization, Modification and Application, InTech Open. https://doi.org/10.5772/47790.

Klaja, J. \& L. Dudek, 2016. Geological interpretation of spectral gamma ray (SGR) logging in selected boreholes. NAFTA-GAZ.

McCarthy, K., K. Rojas, M. Niemann, D. Palmowski, K. Peters \& A. Stankiewicz, 2011. Basic petroleum geochemistry for source rock evaluation. Oilfield Review, 23(2), 32-43.

Nielsen, B.L., Løvborg, L., Sørensen, P. \& Mose, E., 1987. Gamma-ray analysis for $\mathrm{U}$, Th and K on bulk cutting samples from deep wells in the Danish Subbasin and the North German Basin, 82 pp. Unpublished report, Risø National Laboratory, Denmark.

Quirein, J.A., Gardner, J.S., \& Watson, J.T., 1982, Combined natural gamma ray spectral/litho-density measurements applied to complex lithologies. Society of Petroleum Engineers of the American Institute of Mining, Metallurgical and Petroleum Engineers Paper SPE, 11143, $14 \mathrm{p}$.

Ruffell, A., J. McKinley, C. Lloyd \& C. Graham, 2006. Th/K and Th/ U Ratios from Spectral Gamma-Ray Surveys Improve the Mapped Definition of Subsurface Structures. Journal of Environmental \& Engineering Geophysics, 11(1), 53-61. 
Schlumberger 1982: Natural gamma-ray spectrometry. Essentialsof N.G.S. interpretation, 69 pp. Houston, Texas: SchlumbergerEducational Services.

Schlumberger. 1995. Log Interpretation Charts. Schlumberger Wireline and Testing : Sugarland, Texas.

Schnyder, J., A. Ruffell, J.-F. Deconinck \& F. Baudin, 2006. Conjunctive use of spectral gamma-ray logs and clay mineralogy in defining late Jurassic-early Cretaceous palaeoclimate change (Dorset, UK). Palaeogeography, Palaeoclimatology, Palaeo-ecology, 229(4), 303-320.

\footnotetext{
CC () (C) 2020 Journal of Geoscience, Engineering, Environment and Technology. All rights reserved. This is an open access article distributed under the terms of the CC BY-SA License (http://creativecommons.org/licenses/by-
} $\mathrm{sa} / 4.0 /$ ) 